\title{
Methane Emissions from Paddy Rice Fields: Strategies towards Achieving A Win-Win Sustainability Scenario between Rice Production and Methane Emission Reduction
}

\author{
Epule Terence Epule \\ Institute of Environmental Sciences, University of Quebec at Montreal (UQAM) \\ Case postale 8888, succ Centre-Ville, Montréal (QC), H3C 3P8, Canada \\ Tel: 1-514-987-3000 ext 3041 E-mail: epule.terence_epule@courrier.uqam.ca, \\ Changhui Peng \\ Institute of Environmental Sciences, University of Quebec at Montreal (UQAM) \\ Case postale 8888, succ Centre-Ville, Montréal (QC), H3C 3P8, Canada \\ Tel: 1-514-987-3000 ext 3041 E-mail: peng.changhui@uqam.ca \\ Ndiva Mongoh Mafany \\ Sitting Bull College, Fort Yates, ND, USA \\ Telephone: 001701-854-80517Ｅ-mail: landysat@yahoo.com
}

Received: September 15, $2011 \quad$ Accepted: October 28, $2011 \quad$ Published: December 1, 2011

doi:10.5539/jsd.v4n6p188

URL: http://dx.doi.org/10.5539/jsd.v4n6p188

\begin{abstract}
This paper reviews the emissions of methane from Paddy rice fields and the various strategies that can be used to mitigate methane emission while continuing with rice production. The option of setting up a win-win sustainable development approach is based on the fact that rice remains one of the most widely consumed cereals in the world. The paper also seeks to review the emission mechanisms and to illustrate from existing literature that when methane emissions are high under flood conditions (rainy season), there is a reduction in rice output and the reverse is true during periods of less flood. Yet, how can rice be produced without flooding? This paper is mainly a review paper which essentially obtains most of the information by reviewing other studies. The results from the analysis and reviews shows that globally, South East Asia leads in the global rice production and methane emissions chart. During periods of floods emissions are high and this compromises rice yields. The optimum solution to mitigation is based on a synergy of methods and not just on a single method as seen in the review of mitigation strategies.
\end{abstract}

Keywords: Methane emissions, Paddy rice yields, Win-win sustainability

\section{Introduction}

Methane is a vital greenhouse gas and its atmospheric concentration has almost increased three fold since the pre-industrial era (Keppler et al., 2006; Zou et al., 2005). Methane is further important because emissions of about $1 \mathrm{~kg}$ of methane to the atmosphere are 21 times more destructive to the radiation balance than does $1 \mathrm{~kg}$ of carbon dioxide (Denier et al., 2002). As a cause of climate change, methane is only second to carbon dioxide as its global warming potential is 23 times greater than carbon dioxide on a mass balance basis (Towprayoon et al., 2005; Intergovernmental Panel on Climate Change (IPCC), (2001). Furthermore, the desire to consider Paddy rice fields is pertinent because rice remains a vital crop as it is grown on more than 150 million hectares of land globally and humans consume more rice than any other cereal globally (Bloom \& Swisherm, 2010).

Paddy rice fields now constitute a predominant source of anthropogenic atmospheric methane $\left(\mathrm{CH}_{4}\right)$ (Agnihotris et al., 1998). Other sources are enteric fermentation, natural wetlands, landfills, coal mining, gas production and distribution, biomass burning and oil exploitation and distribution. While it is certain that these are the main 
sources, the relative contribution of the different sources to the global picture remains an issue of high uncertainty (Aselmann \& Crutzen, 1987; Zou et al., 2005).

Continual intensification of Paddy rice cultivation will contribute to the gradual rise in atmospheric methane (Inubushi et al., 2001). In addition, a seasonal pattern of variations in methane emissions is observed for Paddy rice fields when compared to fields that are rice free. This is because rice plants stimulate methanogenesis under submerged conditions in the wet season which enhance methane production (Denier et al., 2002).

\section{Objectives and Methodology}

From the aforementioned, this study seeks to use a desk study approach by reviewing existing literature on the contributions of Paddy rice methane emissions to the global methane emissions picture, a review of the seasonal variations in methane emissions with Paddy rice yields. This involves methodological hypothesis validation based on evidence in existing literature that there is an inverse relationship between methane emissions and Paddy rice yields and to review the mechanisms that can be used to reduce Paddy rice methane emissions while at the same time still producing rice (win-win sustainability). The main methodological concept therefore is the 'win-win sustainability' that describes a scenario in which development and environmental protection go hand in hand. In the context of rice production, this means that current production of rice should not be done at the expense of wide scale methane emissions. On the other hand, the desire to reduce methane emissions should not be at the expense of rice production. In a nutshell, rice production should be carried out such that it is enough to meet population needs on the one hand while mitigation strategies should be put in place to curb methane production. While acknowledging the fact that persistent methane emissions will compromise future rice production, win-win sustainable development is one in which current development endeavours enables the needs of current generations to be met without compromising the ability of future generations to meet their own needs, this study aims at reviewing the approaches that can be put in place to attain such a goal (Brundtland, 1987).

\section{Results and Discussions}

\subsection{Paddy rice methane emissions in the Global methane emissions picture}

Globally, most of the methane emissions from Paddy rice fields do occur in and around the tropics, sub-tropics and parts of the temperate boreal. This includes areas like Central and Latin America, Africa and South East Asia (Figure 1 and 3 below) (Aselmann \& Crutzen, 1987). South East Asia emits approximately 10,000 kg of methane per kilometer square or contributes $90 \%$ to the global rice methane emissions chart (see rectangle on Figure 1) (Yan et al., 2009; Aselmann \& Crutzen, 1989). Africa and South America add 3.5\% and 4.7\% to the global Paddy rice methane budget respectively. Within South East Asia, India and China are also the two major dominant rice producing countries (Aselmann \& Crutzen, 1989). So, the areas of high rice production are equally the area of high methane emissions due to rice cultivation (Yan et al., 2009).

The global distribution of rice Paddies varies with latitudes. Most of the cultivation of rice is within latitudes $50{ }^{0}$ $\mathrm{N}$ and $30^{\circ} \mathrm{S}$ of the equator (Aselmann \& Crutzen, 1989). If we correlate this spatial distribution of Paddy fields (Figure 3) with the zones of rife annual Paddy rice methane emissions (Figure 1) we observe that the two zones represent the same region. We can therefore say that most of the zones of high Paddy rice production are equally the zones of high Paddy rice methane emissions and these are principally in the Northern hemisphere as elaborated already.

The total global methane emissions from all sources stand at about 600 Teragrams per year $\left(\right.$ Tgyear $\left.^{-1}\right)($ Denier et al., 2002). Estimates of Paddy rice contributions to the global methane budget have been set at approximately $10 \%$ (Figure 2) and 15\% (Global Methane Initiative (GMI), 2010) and Inubushi et al., 2001) respectively. These estimates are relatively good because their variance of 5 is not too large being that they are independent studies. The main weakness of these estimates is that enteric fermentation is considered as an independent contribution to the global chart, yet enteric fermentation is a process that takes place during rice production in flood waters.

Currently, the rate of emission of $\mathrm{CH}_{4}$ from rice fields is rising at an annual rate of $0.7-1.1 \%$ per year. This is translated to about 18-280 Teragrams per year $\left(\mathrm{Tg} / \mathrm{Y}^{-1}\right)$ which is equal to $10-70 \%$ of anthropogenic methane

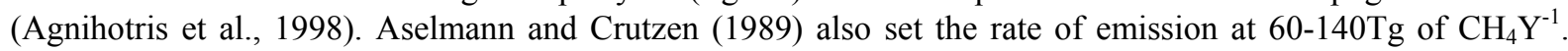
Most of these estimates have not been obtained using the IPCC guide lines. Using the IPCC guide lines and country specific activity data, Yan et al. (2009) observed that global Paddy rice fields would emit $25.6 \mathrm{Tg}^{-1}$. This has a $95 \%$ certainty range of $14.8-41.7 \mathrm{Tg} \mathrm{a}^{-1}$. Whatever the case, this study observes that the wide degree of possible $\mathrm{CH}_{4}$ emission levels heralds the notion of large degrees of uncertainty in the methods. For this reason, Aselmann and Crutzen (1989) propose the use of ecophysiological studies which increase certainty. 


\subsection{Mechanisms of Paddy rice Methane Emissions and seasonal variations in methane emissions and Paddy rice yields}

The main vectors behind methane emissions from Paddy rice fields are methanogenic bacteria. Methanogenic bacteria can be divided into mythlotrophic, obligate chemolithotrophic and quasi-chemolithotrophic microorganisms. Such microorganisms perform well under anaerobic conditions and are responsible for harvesting organic carbon and transforming it into methane, this process is called methanogenesis (Bloom \& Swisher, 2010; Inubushi et al., 2001). The anaerobic conditions are the biochemical pathways of methane production. The source materials for all these reactions are the straws of rice plants which represent the main inputs of organic materials. These materials normally build up and during the rainy season or periods of inundation they decompose and become the main source of methanogenic substrates. As such, the carbon that is not available for seeding is emitted into the soils and is transformed into methane by methanogenic bacteria (Denier et al., 2002; Naser et al., 2007).

Later, other sources of organic carbon such as newly produced plant residues will gain importance. Once the methane is produce from the methanogenic processes it is now transported vertically to the atmosphere through three main pathways. These pathways include diffusion of dissolved methane that reaches the flooded waters, the emergence of bubbles triggered by soil fauna and crop management procedures and finally plant transport by diffusion into the roots and conversion to gaseous methane in the cortex and aerenchyma and subsequent release of methane to the atmosphere through plant micropores (Figure 4) (Wassmann et al., 1993).

Methane emissions from Paddy rice fields tend to follow a seasonal pattern. This means that in the rainy season emissions are higher while at the same time there has been observed reductions in rice output. On the other hand, during the dry season methane emissions are lower and irrigated Paddy fields tend to experience a bumper crop. However, the notion of dry season rice farming does not mean a complete absence of water which will rather have negative effects on rice yields. Emphasis is on cultivation in swampy areas which are less flooded than the wet season fields and have just enough water for survival of rice. As such, the common hypothesis now is that there is an inverse correlation between $\mathrm{CH}_{4}$ emissions and grain yields. Several studies have verified this hypothesis. Firstly, it has been observed that the harvest index (HI- which represents the mass ratio of grain output and the total above ground biomass) is lower in the wet season when methane emissions are high than in the dry season when methane emissions are lower for rice plants (Corton et al., 2000).

In general, cereal output is limited by the supply of assimilates to fill the grains called source limitation and the ability of the reproductive organs to take in the assimilates called sink limitation. The latter is common in rice in the wet season while the former is common in the dry season when the flower clusters are very high. Results from modeled simulations now show that sink limitation does not occur in the dry season but rather showed lower HI values in the wet season with more sink limitation. It is argued that low solar radiation during the preanthesis period results in reduced assimilate supply and the degeneration of spikelets which may led to a reduction in yields and $\mathrm{HI}$ in the wet season while in the dry season, yields and $\mathrm{HI}$ are higher (Denier et al., 2002).

Studies have proven that during the wet season methane emissions are high while during the dry season, methane emissions are low. At the same time, yields are low during the dry season and high during the rainy season (Figure 5). This is explained by the fact that in the wet season, the resultant photosynthesis produces carbon but a shortage of flowers and spikelets makes this carbon not to be available for grain production and therefore low rice output. This amount of carbon not available for seed production gets into the soil as rhizodeposition and as leaf litter fall where they serve as raw material for methanogens, thus, high methane emissions in wet season. In the dry season scenario, much of the carbon is used for seeding and active rice production, thus, a lower methane emission and higher rice output (Sass et al., 1990; Denier van der Gon et al., 2002). The above findings are consistent with the observations of Pschorn et al. (1986) who argue that a seasonal change of daily mean $\mathrm{CH}_{4}$ emission rates from flooded fields between May 3 and September 13, 1985 for three field types (Paddy rice field, field planted with weeds and field which was kept unplanted) showed a variation in emissions as follows: 36.3, 18.4 and $20.1 \mathrm{~g} \mathrm{~m}^{-2}$ for the Paddy rice field, the weed field and the unplanted field respectively. This shows that the Paddy rice field section experienced more emissions of $\mathrm{CH}_{4}$ than the other two sections under flooded rainy season conditions (Figure 6). Similarly, results from laboratory experiments carried out by Pschorn et al. (1986) are also consistent with the field experiments presented above. The laboratory experiments hold that there is increased methanogenesis and production of $\mathrm{CH}_{4}$ when we have rice fields which are submerged than with unvegetated submerged soils (Pschorn et al., 1986). 


\subsection{Agricultural practices to reduce methane emissions from Paddy rice fields}

It has been noted that as human populations continues to increase; the need for more rice cultivation becomes even so evident. With this, there is a parallel risk of more methane emissions. However, if a sustainable society has to be maintained then a win-win situation has to be established. This means that strategies to curb methane emissions must be put in place but these must not be at the expense of rice production. If the latter is the case then, the very notion of sustainability would have been defeated (Brundtland, 1987). This part of this study therefore looks at the different techniques that can be used to reduce methane emissions from Paddy rice fields.

\subsubsection{Water management methods}

Water management has been considered as one of the methods that can be used to reduce methane emissions from Paddy rice fields. Intermittent drainage for example has the advantage of improving oxidative soil conditions by promoting root activity, increases soil bearing capacity and ultimately reducing excess water that causes anaerobic conditions and will also introduce oxygen into the soils thus rendering the area aerobic and also reducing the formation of methane. Mid season drainage enhances nitrogen absorption as well as soil oxidative conditions (Inubushi et al., 2001). In other words, this could be carried out by reducing the amount of water applied to the fields since a net decrease will reduce methane emissions. However, caution will have to be taken to ensure that the water requirement of modern day rice plants is maintained. This is set at approximately $6 \mathrm{~mm}$ per day; lower levels will be very adverse for rice cultivation (Wassmann et al., 1993; Wassmann et al., 2000; Naser et al., 2007).

Closely linked to the water management methods is the control of the pattern of flooding of irrigated rice (creating temporal dry periods). This would include short term droughts and is of great value because rice plants can recover from relatively brief periods of moisture stress if suitable conditions are quickly reestablished. In most parts of South East Asia, this method has been tested and the yields have been almost equal. However, the reaction to moisture stress varies with the stages of development in the rice plant. Research has shown that pre-flowering stages appear more tolerant to moisture stress while the flowering and graining stages are more sensitive to this technique (Wassmann et al., 1993). Therefore, a pattern that considers the water requirements of the rice plants at the different stages would be plausible. Whatever the case, it has been argued that creating such temporal dry periods to curb methane emissions will often result in increased nitrification and denitrification with a net loss of nitrogen (Wassmann et al., 1993). Bloom and Swisher (2010) argue that water management practices that drain rice fields in the middle of the growing season to cut down methane by $15 \%$ to $59 \%$ depend on the availability of additional water to reflood the Paddies and add about 5-9\% more to the cost of production (Bloom \& Swisher, 2010; Li et al., 2005).

Another water management technique is the shift in rice cultivation from wetlands to upland rice cultivation. It has been argued that this will certainly reduce flooding and methane emission but will be of adverse effect to rice yields since yield under dry land conditions are generally much lower than in wetland rice Paddies. According to Wassmann et al. (1993) and $\mathrm{Li}$ et al. (2005) this technique is far from being feasible because most upland rice varieties yield about 1 ton per hectare $(\mathrm{t} / \mathrm{h})$, the modern rice varieties cultivated in upland areas yields about $4 \mathrm{t} / \mathrm{h}$. He argues that this compares weakly to the $7 \mathrm{t} / \mathrm{h}$ for swamp or irrigated or flooded rice. However, Towprayoon et al. (2005) argues that even though drainage reduces methane emissions, it is capable of enhancing Nitrous oxide emission which can reduce yields. This can be established as a wicked problem where one solution creates another problem, the reason why a synergetic or systematic approach is advocated.

\subsubsection{Soil Additives}

Furthermore, the application of organic matter is an important factor. This will also enhance aeration and will further cause an increase in the growth of aquatic weeds. However, this method of draining the land is currently weakened by the fact that, current findings from weeded pots on which Paddy rice was grown show that when aquatic weeds take over they may cause an increase in methane emissions in the long run (Inubushi et al., 200). The mechanism by which this happens is not yet well understood. Inubushi et al. 2001, have investigated the potential of weeds in Paddy fields to produce methane and have observed that fields under weeds do produce more methane than those under no weeds. This method can therefore be effective if application of manure is accompanied by frequent removal of other invasive weeds.

It is argued that the current surge of emissions of methane from terrestrial plants is not properly understood (Schiermeier, 2010). In attempting an explanation it is observed that the emissions cannot be from bacteria activities in the leaves or enzymes of plants in plant cells. They suggested that plants produce methane autonomously without a catalyst such as protein. Instead, the chemical pathway involves pectin. The different sugars in the molecules of pectin are used by plant cells and are constantly being synthesized and degraded and 
this to them could produce methane. However, the exact mechanisms by which this works are still unclear (Keppler et al., 2006; Wassmann et al., 2000).

Another soil additive method used in controlling methane emissions from Paddy rice fields is by controlling the input of straws from rice into the flooded soils. Most of the methane produced is from the decomposition of the rice straws that are often in flooded water. This is done by making sure that the rice straws are not allowed to decay in the flooded water since this will favour the growth of methanogenic bacteria. According to Nagata (2010) the rice straws can be used as feed for cattle while the composted animal manure from the cattle is applied to the Paddy fields as has been the case in Japan. This will invariably increase plant nutrients, retain plant nutrients, increase production stability and quality of rice, decrease methane emissions, promote rice growth and encourage aggregate soil structures. A view supported by Kulshreshtha and Singh (1998). This has been illustrated on Figure 7.

Again, soil amendments could be of great importance in the fight to reduce methane emissions from Paddy rice fields. One way of doing this is through the application of nitrification inhibitors to Paddy soils. Inhibitors such as acetylene and nitrapyrin have been known to have the potential of inhibiting nitrifiers, methanogens and methane oxidizers. Though the ability of nitrapyrin to reduce nitrification has been questioned, recent experiments have shown that encapsulated calcium carbide from which there is a slow release of acetylene to the soil is efficient in the reduction of methane emissions from an artificial Paddy system in a greenhouse. Other studies have also shown a 30\% increase in rice yields with increase acetylene (Wassmann et al., 1993; Yan et al., 2005).

Furthermore, soil amendments geared towards reducing methane emissions could be attained through the application of sulfates. Denier et al. (2001) argue that the application of sulfate fertilizers is often suggested as an amendment method. However, this is not able to reduce methane emissions by $100 \%$. They argue further that for all the experiments carried out, reductions in methane emissions following the application of sulfates was observed. This is explained by the fact that in the presence of sulfates, sulfate reducing bacteria (SRB) will out compete methanogens (methane producing bacteria-MPB) for substrates and this will reduce $\mathrm{CH}_{4}$. Both SRB and MPB compete for the same substrates such as $\mathrm{H}_{2}+\mathrm{CO}_{2}$ or acetate that MPB use in methane production (Pschorn, et al., 1986; Yan et al., 2005; Zou et al., 2005). However, there was never a complete inhibition of methane emissions from rice fields following the application of sulfates because the maximum reduction of methane emissions that can be obtained in rice fields is in the range $60-70 \%$ no matter the amount of sulfates applied. Also, reductions in $\mathrm{CH}_{4}$ at $100 \%$ could be further difficult because $\mathrm{CH}_{4}$ emissions are not controlled only by $\mathrm{CH}_{4}$ production but also by $\mathrm{CH}_{4}$ oxidation and by the gas transport pathways to the atmosphere such as diffusion, ebullition and also related transport (Denier \& Neue, 1994). Uncertainty in this approach is created when (Wassmann et al., 1993; Wassmann et al., 2000; Yan et al., 2005) report that experiments with the application of nitrogen and sulfate fertilizers in an attempt to observe the behaviour of methane rather report a 5 fold increase in methane emission from Californian rice Paddies when compared to unfertilized soils.

\subsubsection{Selection of Cultivar}

Furthermore, a careful selection and breeding of cultivar is an important factor. This approach is rationalized by the fact that rice plants have been seen as one of the main routes for the transmission of methane to the atmosphere. As a recap, rice plants have a well developed aerenchymal system. So, methane produced in the soil by methanogens enters the roots of rice plants and moves by diffusion in the aerenchymal before being transmitted to the atmosphere. Therefore, a mitigation measure to reduce methane emissions to the atmosphere would be to cultivate rice varieties that do not have well developed aerenchymal systems (Wassmann et al., 1993; Zou et al., 2005). This is because rice cultivars vary in their exudation of organic carbon and likewise their support of methanogenesis (Bloom \& Swisher, 2010).

\section{Conclusions}

As the world population continues to rise, the need for more rice cultivation will keep rising. During the wet season, Paddy rice fields tend to produce more methane while at the same time experiencing reductions in rice output. The activities of MPB go a long way to set the stage for methanogenesis. Several mechanisms have been developed to reduce methane emissions such as water management, cultivar selection, soil additives and soil amendments. Whatever the case, most of these methods are $90 \%$ efficient but have a $10 \%$ uncertainty. This study therefore recommends that a synergetic approach in which a combination of these techniques is used will yield better results. 


\section{Acknowledgement}

Special thanks go to the NSERC Canada discovery grant and Sitting Bull College, Fort Yates for funding this study. Thanks also go to Mrs. Naomi Mesame Epule for her assistance. Marline and Mirielle are not left out.

\section{References}

Agnihotris, S., Kulshreshtha, S. A. \& Singh, S. N. (1998). Mitigation strategy to contain methane emission from Rice-fields. Environmental monitoring and Assessment. 58, 95-104.

Aselmann, I. \& Crutzen, J. (1987). Global distribution of natural Freshwater wetlands and Rice Paddies, their primary productivity, Seasonality and Possible Methane emissions. Journal of Atmospheric Chemistry. 8, 307-358.

Bloom, A. \& Swisher, M. (2010). Emissions from Rice Production. Encyclopedia of Earth. Eds. Cutler J. Cleveland [Online] Available: http://www.eoearth.org/article/Emissions_from_Rice_Production?topic=54486 (June 15, 2011)

Brundtland, G. H. (1987). Presentation of the Report of the World Commission on Environment and Development to the UNEP'S $14^{\text {th }}$ Governing Council session. World Commission on Environment and Development.

Corton, T. M., Bajita, J. B., Grospe, F. S., Pamplona, R. R., Assis, C. A., Wassmann, R., Lantin, R. S. \& Buendia, L. V. (2000). Methane emission from irrigated and intensively managed rice fields in Central Luzon (Philippines). Nutrient cycling in Agroecosystems. 58, 37-53.

Denier Van der Gon, H. A. C., Bodegom, P. M. V., Wassmann, R., Lantin, R. S. \& Corton, T. M. (2001). Sulfate-Containing Amendments to reduce Methane emissions from rice fields: Mechanisms, effectiveness and cost. Mitigation and adaptation strategies for Global change. 6, 71-89.

Denier Van der Gon, H. A. C., Kropff, M. J., Van Breemen, N., Wassmann, R., Lantin, R. S., Aduna, E., Corton, T. M. \& Van Laar. (2002). Optimizing grain yields reduces $\mathrm{CH}_{4}$ emissions from rice paddy fields, $P N A S$, 17, 12021-12024.

Denier Van der Gon, H. A. C. \& Neue, H. U. (1994). Impact of Gypsum application on methane emission from a wetland rice field. Global Biogeochemchemical cycles. 8, 127-134.

Global Methane Initiative (GMI). (2010). Global Methane Emissions and Mitigation Opportunities. GMI, [Online] Available: www.globalmethane.org (August, 17, 2011)

Inubushi, K., Sugii, H., Nishino, S. \& Nishino, E. (2001). Effects of Aquatic weeds on Methane emission from Submerged Paddy soils. American Journal of Botany. 88, 975-979.

Intergovernmental Panel on Climate Change. (2001). Climate Change 2001. The Scientific Basis. Cambridge, New York, Cambridge University Press.

Keppler, F., Hamilton, J. T. G., Brab, M. \& Rockmann, T. (2006). Methane emissions from terrestrial plants under aerobic conditions. Nature. 439, 187-191.

Li, C., Frolking, S., Xiao, X., Moore III, B., Boles, S., Qui, J., Huang, Y., Salas, W. \& Sass, R. M. (2005). Modeling impacts of farming management alternatives on $\mathrm{CO}_{2}, \mathrm{CH}_{4}$ and $\mathrm{N}_{2} \mathrm{O}$ emissions: A case study for water management of rice agriculture in China. Global Biogeochemical cycles. 19, 1-10. http://dx.org/10.1029/2004GB002341

Nagata, A. (2010). Mitigation of Methane Emissions from Rice Paddy fields in Japan. Report of the Ministry of agriculture, forestry and fisheries. Japan.

Naser, H. M., Nagata, O., Tamura, S. \& Hatano, R. (2007). Methane emissions from five paddy fields with different amounts of rice straw application in central Hokkaido, Japan. Soil Science and Plant Nutrition. 53, 95-101. http://dx.org/10.1111/j.1747-0765.2007.00105.x

Pschorn, A. H., Conrad, R. \& Seiler, W. (1986). Effects of vegetation on the emission of methane from submerged paddy soil. Plant and soil. 92, 223-233.

Sass, R. M., Fisher, F. M., Harcombe, P. A. \& Turner, F. T. (1990). Methane production and emission in a Texas rice field. Global biogeochemical cycle. 4, 47-68.

Schiermeier, Q. (2006). The methane mystery. Nature special report. 442, 730-731. 
Towprayoon, S., Smakgahn, K. \& Poonkqew, S. (2005). Mitigation of methane and nitrous oxide emissions from drained irrigated rice fields. Chemosphere. 59, 1547-1556. http://dx.org/10111/0004-5608.00205

Wassmann, R., Papen, H. \& Rennenberg, H. (1983). Methane emissions from rice Paddies and Possible Mitigation Strategies. Chemosphere. 26, 201-217.

Wassmann, R., Lantin, R. S., Neue, H. U., Buendia, L. V., Corton, T. M. \& Lu, Y. (2000). Characterization of methane emissions from rice fields in Asia. III. Mitigation options and future research needs. Nutrient Cycling in Agroecosystems. 58, 23-36.

Yan, X., Akiyama, H., Yagi, K. \& Akimoto, H. (2009). Global estimates of the inventory and mitigation potential of methane emissions from rice cultivation conducted using the 2006 Intergovernmental Panel on Climate Change Guidelines. Global Biogeochemical cycles. 23, http://dx.doi.org/10.1029/2008GB003299

Yan, X., Yagi, K., Akiyama, H. \& Akimoto, H. (2005): Statistical analysis of major variables controlling methane emissions from rice fields. Global Change Biology. 11, 1131-1141. http://dx.doi.org/10.1111/j.1365-2486.2005.00976.x

Zou, X., Huang, Y., Jiang, J., Zheng, X. \& Sass, R. (2005). A 3-Year field measurement of methane and nitrous oxide emissions from rice paddies in China: Effects of water regime, crop residue and fertilizer application. Global Biogeochemical Cycles. 19. http://dx.doi.org/10.1029/2004GB002401

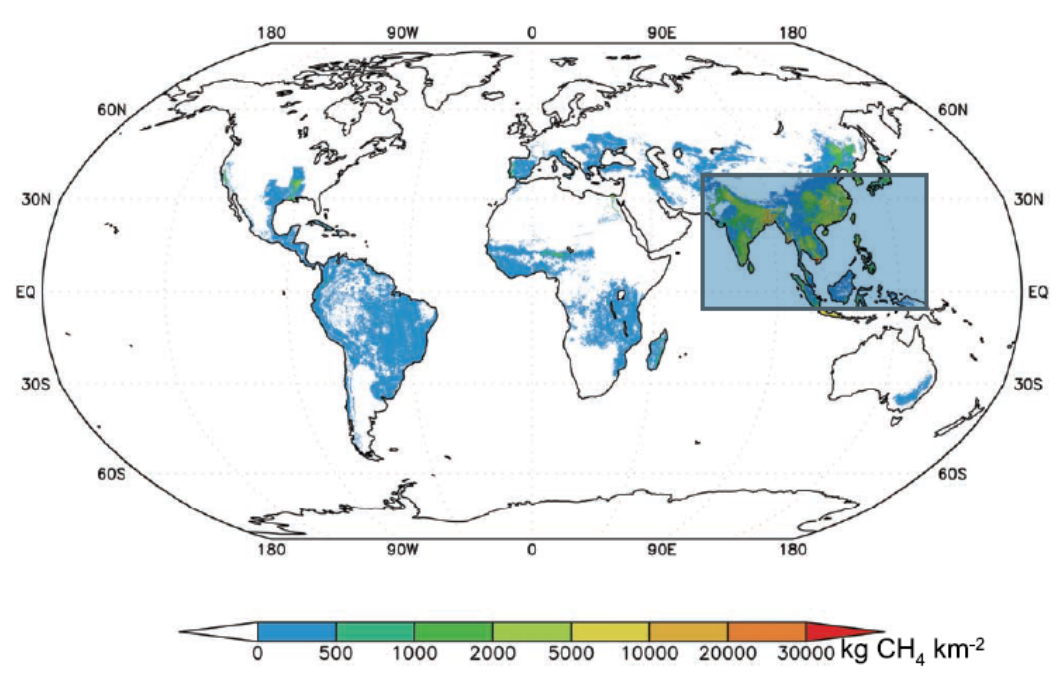

Figure 1. Global estimates of annual methane emission from global rice Paddies at Spatial resolution of 5 minutes showing South East Asia in the rectangle as the contributor of about $90 \%$ of global methane from rice cultivation.

Source: Modified from Yan et al, (2009).

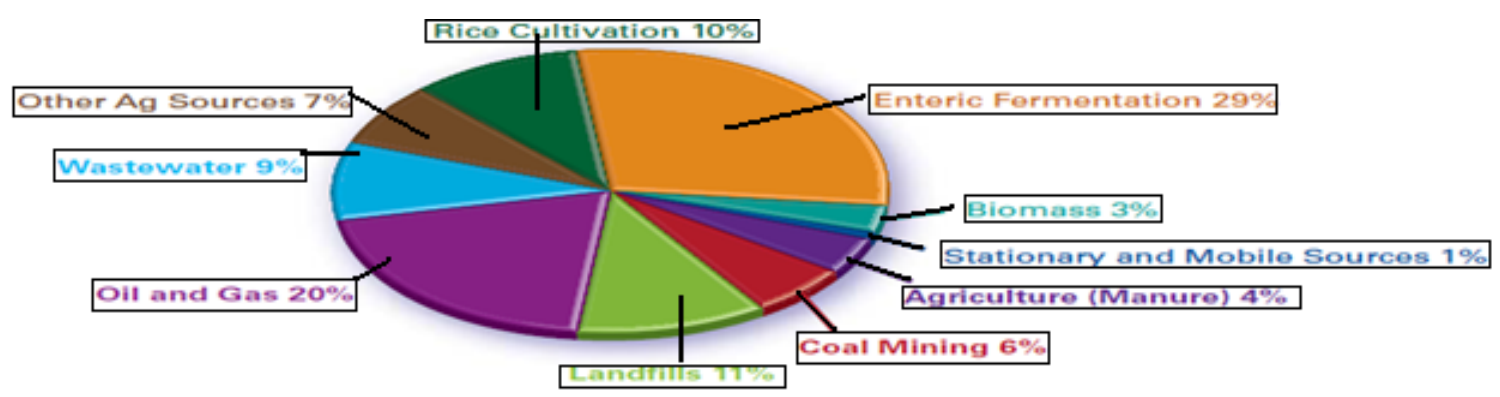

Figure 2. Global Anthropogenic methane emission by source.

Source: Modified from Global methane Initiative, (2010). 

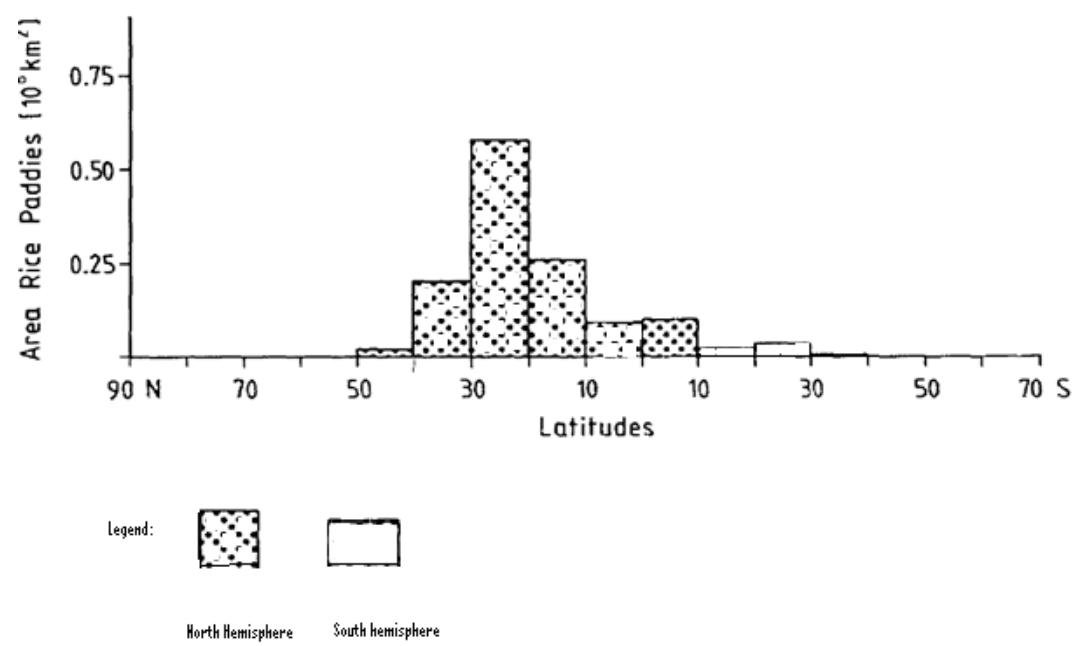

Figure 3. Distribution of rice Paddies with latitude.

Source: Modified from Aselmann \& Crutzen, (1989).

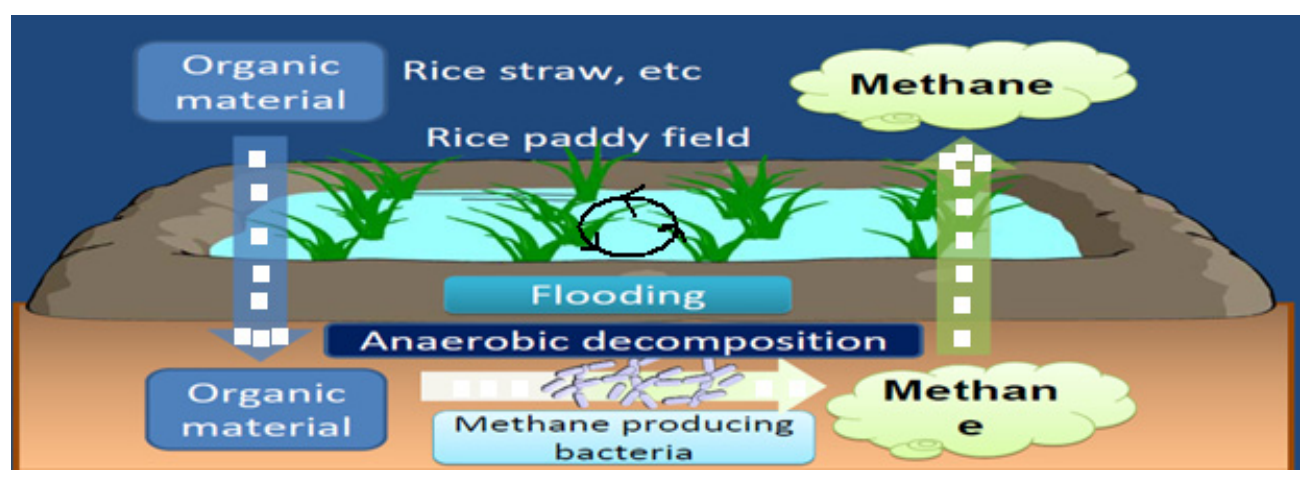

Figure 4. Mechanisms of Methane emissions from Paddy rice field in Japan.

Source: Modified from Nagata, 2010.

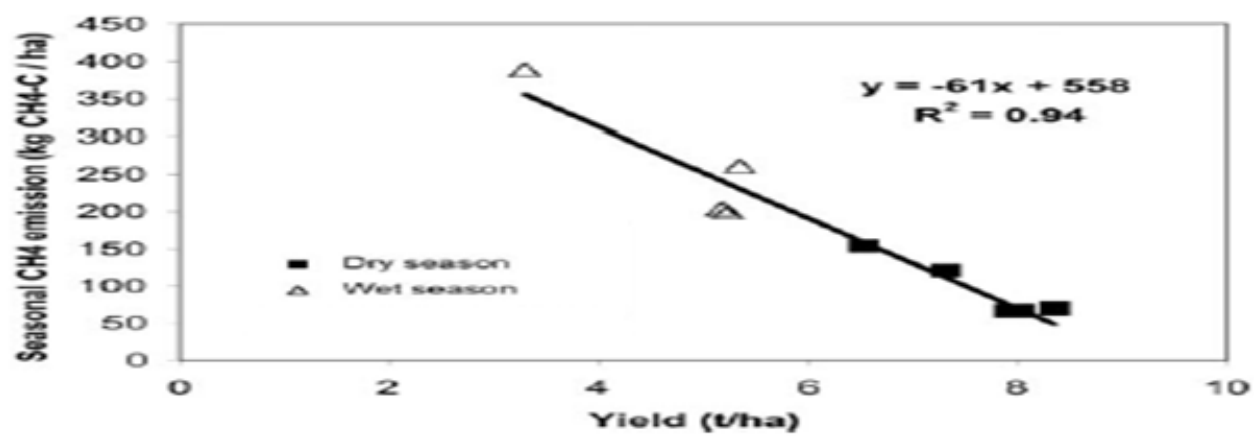

Figure 5. Seasonal methane emission as a function of grain output in Maligaya, Philippines that shows the seasonal variations in methane emissions and grain output. The black squares represent the dry season while the triangles represent the wet season. As seen on the graph, when methane emission (y axis) is highest $\left(350 \mathrm{CH}_{4}-\mathrm{C}\right.$ per hectare), the yields are low at about 3.7 (tons per hectare). This also corresponds with the triangles which means this is during the wet season. On the other hand, we observe that when methane emissions are lowest (50 $\mathrm{CH}_{4}-\mathrm{C}$ per hectare-t/ha) there is a higher response in output ( $\left.8 \mathrm{t} / \mathrm{ha}\right)$. This also corresponds to the black squares which represent the dry season.

Source: Modified from Denier van der Gon et al. (2002). 


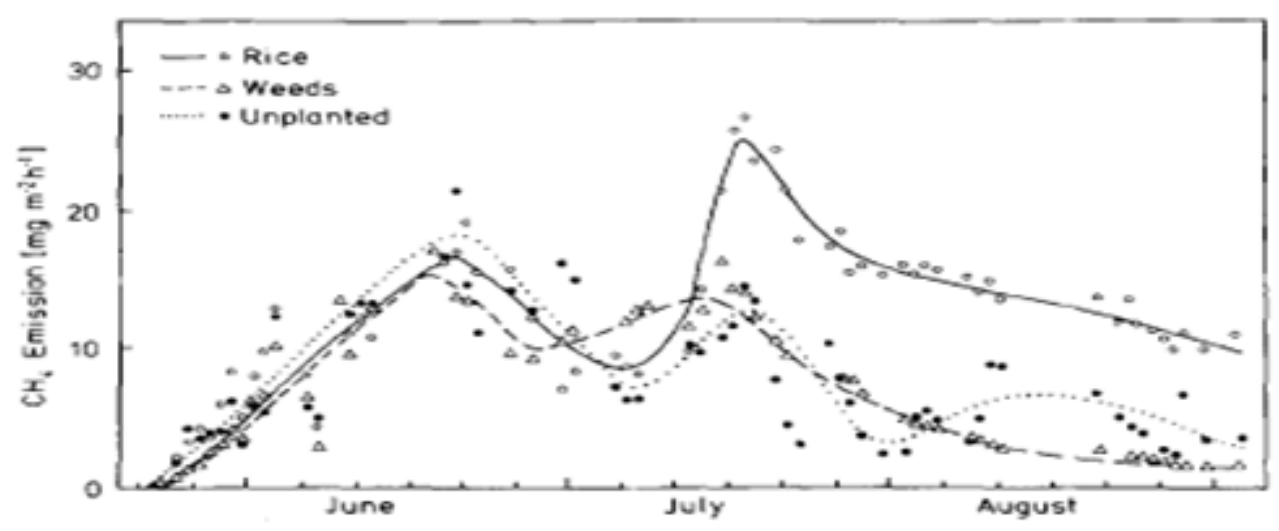

Figure 6. Seasonal change in methane emissions from rice fields, Weeds Field and Unplanted fields.

(As seen on the Figure above, the solid lines represent emissions from rice fields, the dotted lines with diamonds represent emissions from weed fields and the purely dotted lines represent emissions from unplanted fields. The data points are daily mean values of 8 individual determinations by flux measurements in 3 hours rhythm. The emissions where recorded in May 22 and the fields were flooded on May 3 and planted on May 5. As seen on the graph, the solid lines end up dominating the entire methane emissions picture thus supporting the statement that Paddy rice field produce more methane under flooded conditions.)

Source: Modified from Pschorn, et al. (1986) \& Nagata (2010).

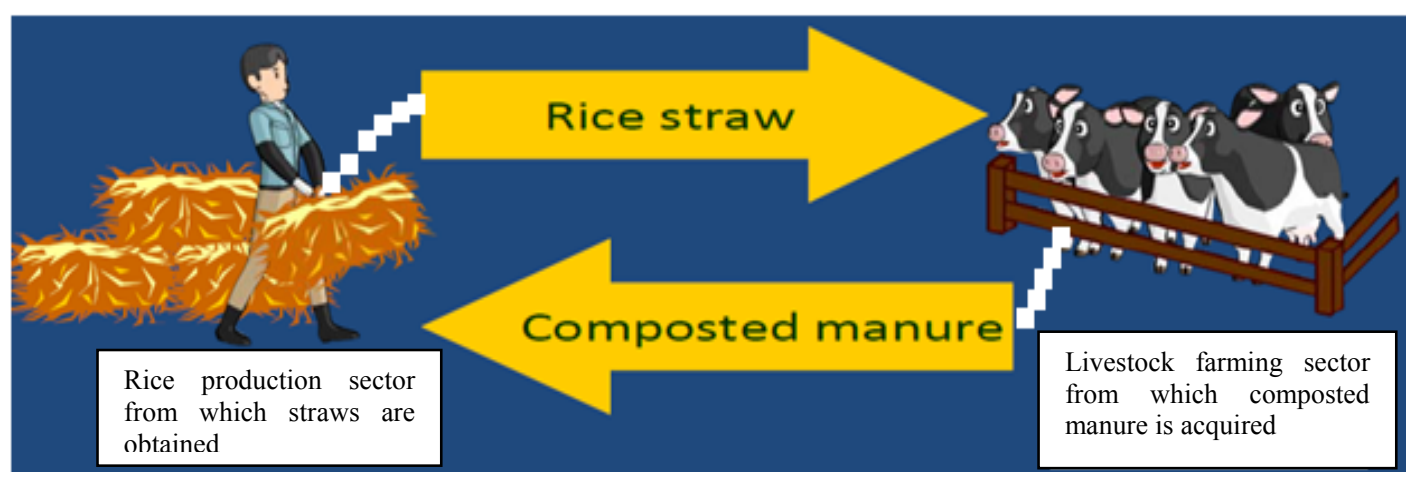

Figure 7. Exchange of rice straw and composted manure.

Source: Modified from Nagata (2010). 